\title{
Motor Tic
}

National Cancer Institute

\section{Source}

National Cancer Institute. Motor Tic. NCI Thesaurus. Code C116759.

A tic affecting muscle movement. 